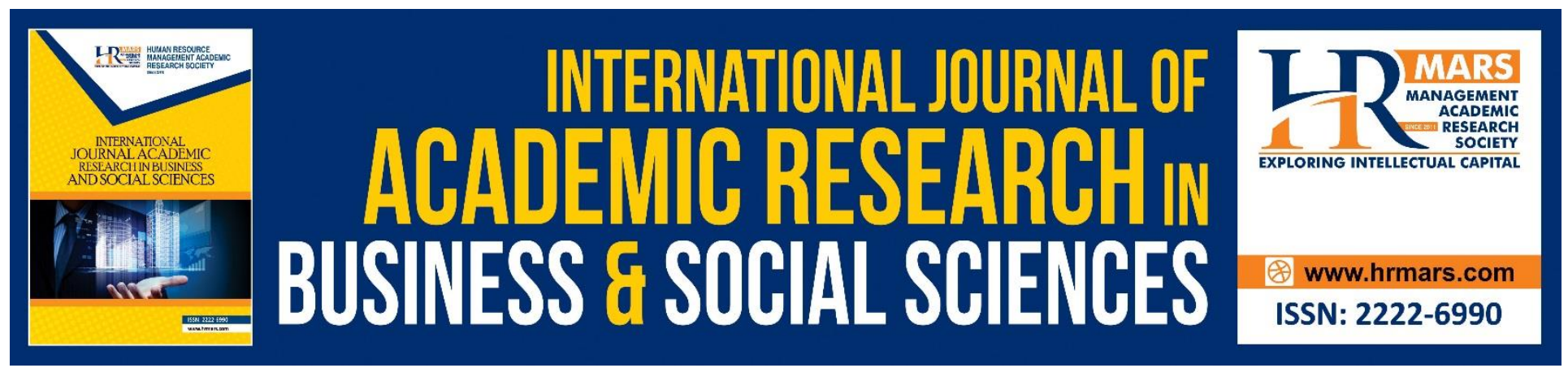

\title{
The Importance of English Listening and Speaking Skills to Preschool Children in Malaysia
}

Norshimar Akmar Hashim, Mazlina Che Mustafa, Azli Ariffin, Zarina Eshak

To Link this Article: http://dx.doi.org/10.6007/IJARBSS/v10-i7/7614

DOI:10.6007/IJARBSS/v10-i7/7614

Received: 09 April 2020, Revised: 10 May 2020, Accepted: 20 June 2020

Published Online: 17 July 2020

In-Text Citation: (Hashim et al., 2020)

To Cite this Article: Hashim, N. A., Mustafa, M. C., Ariffin, A., \& Eshak, Z. (2020). The Importance of English Listening and Speaking Skills to Preschool Children in Malaysia. International Journal of Academic Research in Business and Social Sciences, 10(7), 838-844.

Copyright: @ 2020 The Author(s)

Published by Human Resource Management Academic Research Society (www.hrmars.com)

This article is published under the Creative Commons Attribution (CC BY 4.0) license. Anyone may reproduce, distribute, translate and create derivative works of this article (for both commercial and non-commercial purposes), subject to full attribution to the original publication and authors. The full terms of this license may be seen

at: http://creativecommons.org/licences/by/4.0/legalcode

\section{Vol. 10, No. 7, 2020, Pg. 838 - 844}

Full Terms \& Conditions of access and use can be found at http://hrmars.com/index.php/pages/detail/publication-ethics 


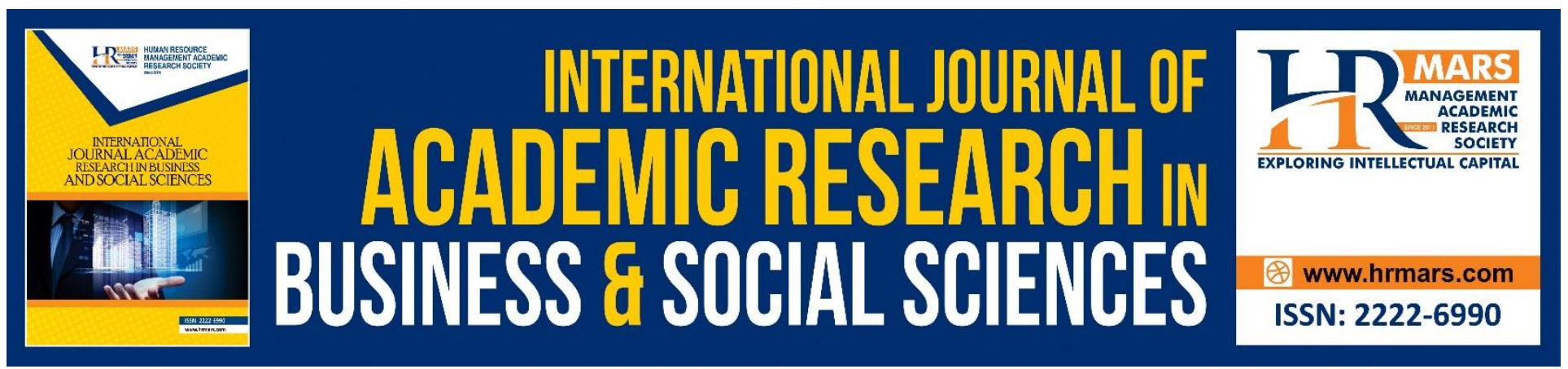

\title{
The Importance of English Listening and Speaking Skills to Preschool Children in Malaysia
}

\section{Norshimar Akmar Hashim, Mazlina Che Mustafa, Azli Ariffin, Zarina Eshak}

Faculty of Human Development, Sultan Idris Education University, 35900 Tanjong Malim, Perak. Malaysia.

Email: norshimar@gmail.com, mazlina.cm@fpm.upsi.edu.my, azli@fpm.upsi.edu.my, zarinaeshak79@gmail.com

\begin{abstract}
This study aims to examine the importance of English listening and speaking skills in preschool from teachers' perspectives. A Likert-based survey with a questionnaire was analyzed by percentage. The sample selection is composed of 100 randomly selected preschool teachers in Kuantan, Pahang Malaysia. A total of 98 participants (98\%) agreed that teachers' knowledge on the English language was important in developing children's listening and speaking skills. Meanwhile, 99 participants (99\%) agreed that teaching skills are important in developing children's listening and speaking skills. A total of 99 participants (99\%) agreed that teachers' English competency was important to produce children who could listen well. Finally, 98 participants (98\%) agreed that teachers' competency strongly influenced children's English Language speaking skills. The implication of this study highlights the needs to help teachers develop effective teaching strategies for preschool children's listening and speaking English skills.
\end{abstract}

Keywords: Listening Skills, Speaking Skills, English Language, Teaching Strategy, Preschool Children.

\section{Introduction}

Children's ability to use English as a second language and as an interaction tool in daily life becomes one of the Preschool Curriculum's objectives (Ministry of Education, 2017). The curriculum component aims to ensure that children can listen actively through meaningful interactions with suitable language activities in the respective language (Baker et al., 2016). As speaking skills are used in verbal interactions in teaching and learning activities, they are the first components to ensure that the children interact with teachers and friends (Gu, 2015). One of the aims of National StandardBased Preschool Curriculum and Assessment (Ministry of Education, 2017) is to use English as a second language in listening and speaking for preschool children's verbal interaction (Ministry of Education, 2017). To achieve this aim, MOE allocates 600 minutes of interaction session in English and another 600 minutes' session in Bahasa Malaysia. However, 400 minutes are given to the preschools which use other languages such as Tamil and Chinese as the primary language of 
INTERNATIONAL JOURNAL OF ACADEMIC RESEARCH IN BUSINESS AND SOCIAL SCIENCES Vol. 10, No. 7, July, 2020, E-ISSN: 2222-6990 @ 2020 HRMARS

instruction (Ministry of Education, 2017). The changes of the minimum hour communication strand are to increase English language use in Early Childhood Education (ECE) and to provide excellent opportunities for children to have more time to acquire and learn English (Siti Hamira Md Ngajib, 2018).

Communication in a foreign language largely depends on listening and speaking skills (Cabell et al., 2015). For this reason, the mastery of listening and speaking skills in English as the second language is a priority these days (Idrissova et al., 2015). It is necessary to equip the students for them to become versatile communicators. Furthermore, English language is spoken all over the world and thus, it attains the status of global language.

\section{Research Question}

The following research questions have been proposed as the basis for this study:

1. How is the knowledge important in developing the content of listening and speaking English in preschool?

2. How are skills important in developing the content of listening and speaking English in preschool?

3. How far does the competence of teachers in English affect the listening skills of preschool children?

4. How far does the competence of teachers in English affect the speaking skills of preschool children?

\section{Theory}

The theoretical framework of this study derives from the synthesis of the literature review on the listening and speaking skills theory, teaching and learning theory and teaching model. The theoretical framework for this study is the combination of the following theories and model:

(i) Nativist theory (Chomsky, 1957) and Socio-Cultural theory (Vygotsky, 1962)

(ii) The Monitor Model (Krashen,1985) and Teaching Model Sim (1971)

Nativist Theory founded by Noam Chomsky in 1957. Chomsky (2000) states that humans' speaking capability has long existed in the structure of the brain. According to Chomsky, all children naturally have a language acquisition device (LAD), which is a system that enables children to combine words. The system is to understand the rules of the pronunciation and the meaning of the sentences heard when they have mastered particular vocabulary. At the same time, LAD is becoming a form of storing for the grammar rules existing in human minds. Another perspective of language acquisition is that children can process words in the language they listened to since young.

Socio-Cultural Theory was introduced by Vygotsky in 1962. Vygotsky believes that children's language, cognitive, and social capabilities can be enhanced through social support and interaction. Vygotsky states that the learning experienced by children only functions when they interact with people around them, and when they perform collaboration with their peers (Thomas, 2005). Children's intelligence will determine just how fast they can catch up on the concept and function of meaningful words that they are listening to. With a sufficient amount of vocabulary, listening to phrases in English being used by the teacher will prepare the children to speak well (Arafat Hamouda, 2013). In this study, both theories are related to each other to show the importance of listening and speaking skills to preschool children. 
INTERNATIONAL JOURNAL OF ACADEMIC RESEARCH IN BUSINESS AND SOCIAL SCIENCES Vol. 10, No. 7, July, 2020, E-ISSN: 2222-6990 @ 2020 HRMARS

Krashen (1985) explains that the second language learning process occurs in children over the age of 5 when the second language learning is no longer natural. At this age, listening skill is the skill that has to be actively developed by the teacher in order for them to speak English naturally. Sim Model highlights on the teacher, objectives, and lesson content. Children became the focus with regard to their achievement of learning objectives. In determining the objectives and contents of the lesson, the children's existing knowledge should be taken into account. The tools include the media and techniques used to present the content. The teacher determines the content of the lesson after taking into consideration the children's abilities (Khansir \& Zaab, 2015). In each lesson, the objectives were assessed in terms of the achievement of the children and teachers use them to improve their teaching. Sim Model is useful to teachers as they help teachers plan their lessons by taking into account essential elements such as materials, teaching, and assessment.

Theoretical Framework

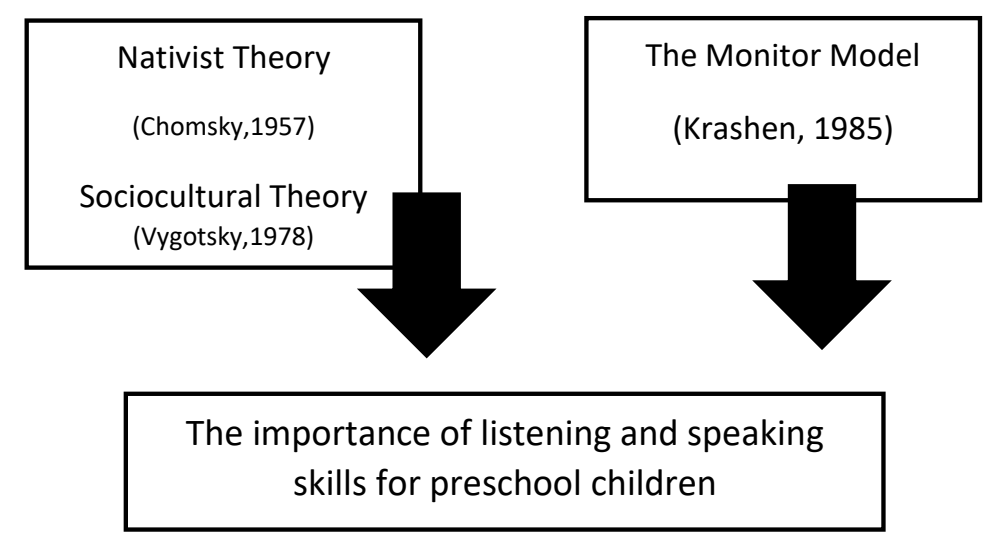

Figure 1. Theoretical Framework

\section{Methodology}

\section{Sampling}

A total of 100 preschool teachers participated in this study. They are from Kuantan, Pahang, Malaysia. There were 90 (90\%) women and 10 (10\%) men, with 57 (57\%) participants mostly between the age of 31-40 years.

\section{Instrument}

Data is collected through two-part questions of questionnaire. Part I and II consist of five-point Likert scale questions. This section of the analysis uses frequency and percentage to obtain the following information:

Part I: Respondent's Profile (5 items)

Part II: The Importance of Listening and Speaking Skills in Preschools (18 items)

\section{Finding and Discussion}

The feedback from the research questions revealed that respondents' experience of being a preschool teacher reflected a new set of themes to answer all the research questions. The theme is the importance of knowledge in developing English listening and speaking skills content for 
INTERNATIONAL JOURNAL OF ACADEMIC RESEARCH IN BUSINESS AND SOCIAL SCIENCES Vol. 10, No. 7, July, 2020, E-ISSN: 2222-6990 @ 2020 HRMARS

preschool children. Participants' responses to the importance of the knowledge in listening and speaking skill content for preschools are shown in Table 1 below.

For the theme, Essential skills in developing the content of the teaching strategy model in listening and speaking skills, participants' responses to appropriate skills and teaching strategies for teaching listening and speaking to preschool children are shown in Table 2.

Teachers' English competencies are important for producing preschool children with good listening skills. Participants 'perceptions of the importance of teacher competence may influence preschool children's listening skills and these are shown in Table 3.

Teachers' English competencies are important for producing preschool children with good speaking skills. Participants 'perceptions of the importance of teacher competence may influence preschool children's speaking skills and these are shown in Table 4.

Table 1. Participants' responses on the importance of the knowledge of teaching strategy in the listening and speaking skill content for preschools

\begin{tabular}{|c|c|c|c|c|c|}
\hline \multirow[t]{2}{*}{ Item } & \multicolumn{5}{|c|}{ Frequency/Means } \\
\hline & $\begin{array}{l}1 \\
\text { (strong } \\
\text { disagree) }\end{array}$ & $\begin{array}{l}2 \\
\text { (Do } \\
\text { not } \\
\text { agree) }\end{array}$ & $\begin{array}{l}3 \\
\text { (dis } \\
\text { agree) }\end{array}$ & $\begin{array}{l}4 \\
\text { (agree) }\end{array}$ & $\begin{array}{l}5 \\
\text { (strongly } \\
\text { agree) }\end{array}$ \\
\hline $\begin{array}{l}\text { The importance of the knowledge in } \\
\text { developing the content for listening and } \\
\text { speaking skills English for preschool children }\end{array}$ & - & - & 2 & 33 & 65 \\
\hline & - & - & $2 \%$ & $33 \%$ & $65 \%$ \\
\hline
\end{tabular}

Based on the results of Table 1, the knowledge of teaching strategy is important to develop the content of an English language listening and speaking model in preschool. A total of 98 participants (98\%) agreed and strongly agreed that knowledge was important in developing the content of the English language listening and speaking model in preschool. Having this model helps teachers use the right strategies in teaching listening and speaking skills to preschool children.

Table 2. Participants' responses to appropriate skills and teaching strategies for teaching listening and speaking to preschool children

\begin{tabular}{|c|c|c|c|c|c|}
\hline \multirow[t]{2}{*}{ Item } & \multicolumn{5}{|c|}{ Frequency/Means } \\
\hline & $\begin{array}{l}1 \\
\text { (strong } \\
\text { disagree) }\end{array}$ & $\begin{array}{l}2 \\
\text { (Do } \\
\text { not } \\
\text { agree) }\end{array}$ & $\begin{array}{l}3 \\
\text { (dis } \\
\text { agree) }\end{array}$ & $\begin{array}{l}4 \\
\text { (agree) }\end{array}$ & $\begin{array}{l}5 \\
\text { (strongly } \\
\text { agree) }\end{array}$ \\
\hline $\begin{array}{l}\text { Essential skills in developing the content of } \\
\text { the teaching strategy model in listening and } \\
\text { speaking skills }\end{array}$ & - & - & 1 & 37 & 62 \\
\hline & - & - & $1 \%$ & $37 \%$ & $62 \%$ \\
\hline
\end{tabular}

Based on the results of Table 2, it is shown that appropriate skills are important in developing the content of the English language listening and speaking teaching strategies for children. Preschool teachers also stated that having the right skills can help to develop the teaching strategy model for 
INTERNATIONAL JOURNAL OF ACADEMIC RESEARCH IN BUSINESS AND SOCIAL SCIENCES Vol. 10, No. 7, July, 2020, E-ISSN: 2222-6990 @ 2020 HRMARS

listening and speaking skills. A total of 99 participants (99\%) agreed that the skills in developing effective listening and speaking skills models are very important.

Table 3. Participants 'perceptions of the importance of teachers' competency may influence preschoolers' listening skills

\begin{tabular}{llllll}
\hline Item & \multicolumn{5}{c}{ Frequency/Means } \\
\hline & $\begin{array}{c}1 \\
\text { (strongly } \\
\text { disagree) }\end{array}$ & $\begin{array}{l}\text { (Do } \\
\text { not } \\
\text { agree) }\end{array}$ & $\begin{array}{l}\text { (dis } \\
\text { agree) }\end{array}$ & $\begin{array}{c}\text { (agree) } \\
\text { (strongly } \\
\text { agree) }\end{array}$ \\
$\begin{array}{l}\text { Teachers' English competencies are important } \\
\text { for producing preschool children with good }\end{array}$ & - & - & 1 & 40 & 59 \\
listening skills. & & & & & \\
\hline & - & - & $1 \%$ & $40 \%$ & $59 \%$
\end{tabular}

Based on the results of Table 3, it is shown that teachers' English competence is important for producing children with good English listening skills. A total of 99 participants (99\%) agreed and strongly agreed that for children to develop good listening skills they need a competent English teacher. The preschool children need to be able to understand what they have listened to.

Table 4. Participants 'perceptions of the importance of teacher competence may influence preschoolers' speaking skills

\begin{tabular}{llllll}
\hline Item & \multicolumn{5}{c}{ Frequency/Means } \\
\hline & 1 & 2 & 3 & 4 & 5 \\
(strongly & $\begin{array}{l}\text { (Do } \\
\text { disagree) } \\
\text { not } \\
\text { (dis }\end{array}$ & $\begin{array}{l}\text { (agree) } \\
\text { agree) }\end{array}$ & & $\begin{array}{l}\text { (strongly } \\
\text { agree) }\end{array}$ \\
$\begin{array}{l}\text { Teachers' English competencies are important } \\
\text { for producing preschool children with good } \\
\text { speaking skills }\end{array}$ & - & - & 2 & 40 & 58 \\
\hline & & & & & \\
\hline
\end{tabular}

Based on the result of Table 4, it is shown that preschool teachers agreed that teachers' English competencies are important for producing preschool children with good speaking skills. There are 98 participants (98\%) who agreed and strongly agreed to the statement.

An overall analysis shows that preschool teachers agreed that a model of English language teaching strategies in listening and speaking skills for preschool children should be developed. This is likely because preschool teachers feel that it will help them to teach preschool children in a more appropriate way. In addition, they find listening skills important for preschool children to respond well to the things they have listened.

\section{Conclusion}

This study was conducted to identify the feedback from preschool teachers on the importance of developing a teaching strategy model for preschool listening and speaking skills. Teaching needs to be tailored to the children's level and needs. All aspects such as teachers' background, experience, 
INTERNATIONAL JOURNAL OF ACADEMIC RESEARCH IN BUSINESS AND SOCIAL SCIENCES

Vol. 10, No. 7, July, 2020, E-ISSN: 2222-6990 @ 2020 HRMARS

educational level and feedback should be considered in developing a teaching strategy in the listening and speaking skills model for preschools.

\section{Corresponding Author}

Assoc. Prof. Dr. Mazlina Che Mustafa

Director.NCDRC Complex Sultan Azlan Shah Campus, Sultan Idris Education University, Proton City 25200 Tanjung Malim. Perak

Email: mazlina.cm@fpm.upsi.edu.my

\section{References}

Baker, D. L., Mogna, V., Rodriguez, S., Farmer, D., \& Yovanoff, P. (2016). Building the Oral Language of Young Hispanic Children Through Interactive Read Alouds and Vocabulary Games at Preschool and at Home. Journal of International Special Needs Education. v19 n2 p81-94

Cabell, S. Q., Justice, L. M., McGinty, A. S., DeCoster, J., \& Forston, L. D. (2015). Teacher-child conversations in preschool classrooms: Contributions to children's vocabulary development. Early Childhood Research Quarterly, 30(PA), 80-92.

https://doi.org/10.1016/j.ecresq.2014.09.004

Chomsky, N. (1957). Logical structures in language. American Documentation, 8(4), 284-291. doi:10.1002/asi.5090080406

Gu, L. (2015). Language ability of young English language learners: Definition, configuration, and implications. Language Testing. 32(1) 21-38. https://doi.org/10.1177/0265532214542670

Thomas, M. (2005). Theories of second language acquisition: Three sides, three angles, three points. Second Language Research, 21(4), 393-414. https://doi.org/10.1191/0267658305sr258ra

Idrissova, M., Smagulova, B., \& Tussupbekova, M. (2015). Improving Listening and Speaking Skills in Mixed Level Groups (on the Material of New English File). Procedia - Social and Behavioral Sciences, 199, 276-284. https://doi.org/10.1016/j.sbspro.2015.07.517

Khansir, A. A., \& Zaab, M. (2015). The Impact of Process Ability Theory on the Speaking Abilities of Iranian EFL Learners. Journal of Language Teaching and Research, 6(2), 343. https://doi.org/10.17507/jltr.0602.14

Krashen, S. (1985). The Input hypothesis: Issues and implications. New York: Longman.

Ministry of Education. (2017). KSPK English Language Teacher's Kit. Ministry of Education.

Ngajib, M. S. H. (2018). Teachers' Needs, Skills and Knowledge for Teacher English Through Effective Interaction with Children. University Pendidikan Sultan Idris.

Thomas, M. (2005). Theories of second language acquisition: Three sides, three angles, three points. Second Language Research, 21(4), 393-414. https://doi.org/10.1191/0267658305sr258ra

Vygotsky, L. (1962). Studies in communication. Thought and language (E. Hanfmann \& G. Vakar, Eds.). Cambridge, MA: MIT Press. https://doi.org/10.1037/11193-000 